\title{
A large landslide in Zigui County, Three Gorges area
}

\author{
F.C. Dai, J.H. Deng, L.G. Tham, K.T. Law, and C.F. Lee
}

\begin{abstract}
On 13 July 2003, a landslide with a volume of approximately $20 \times 10^{6} \mathrm{~m}^{3}$ occurred on the left bank of the Qinggan River, Zigui County, Hubei Province, China. As a result, 14 people died and 10 people are missing. A landslide dam was formed, blocking the Qinggan River. A channelized diversion was constructed for prevention of upstream flooding and damage downstream caused by dam breaching. The landslide was a typical translational rockslide in weathered shale and sandstone, a block of which slipped down along the bedding plane. It is estimated that the landslide was caused by the combined effect of the following factors: $(i)$ a bedding plane between incompetent weathered shale and competent sandstone that daylights at or is shallowly buried at the bottom of the Qinggan River; (ii) a thin layer of clayey soil acting as the slip plane that is likely a preexisting shear surface; (iii) excavation of the shale as raw material for brick fabricating on the slope; and (iv) a combination of prolonged rainfall and reservoir impounding.
\end{abstract}

Key words: landslide, landslide dam, rainfall, impounding, Three Gorges area.

Résumé : Le 13 juillet 2003, un glissement ayant un volume d'environ $20 \times 10^{6} \mathrm{~m}^{3}$ s'est produit sur la rive gauche de la rivière Qinggan, dans le comté de Zigui de la province de Hubei. Il en a résulté 14 morts et 10 personnes disparues. Un barrage formé par les résidus du glissement a bloqué la rivière Qinggan. Un canal de diversion a été construit pour prévenir les inondations en amont et les dommages potentiels causés par une brèche dans le barrage. Le glissement était un mouvement de roche par translation typique de schiste et de grès, dont un bloc a glissé le long d'un plan de littage. On estime que le glissement a été causé par l'effet combiné des facteurs suivants: ( $i$ ) un plan de littage entre le schiste altéré faible et le grès compact qui voit le jour ou est faiblement enfoui au fond de la rivière Qinggan; (ii) une mince couche de sol argileux qui agit comme plan de glissement qui semble être une surface de cisaillement préexistante; (iii) l'excavation du schiste dans la pente comme matière première pour la fabrication de briques; et (iv) une combinaison de chutes de pluie prolongées et de remplissage du réservoir.

Mots clés : glissement, barrages de débris de glissement, chutes de pluie, remplissage de réservoir, région des Three Gorges.

[Traduit par la Rédaction]

\section{Introduction}

Landslides are common in the Three Gorges area of China because of the narrow steep valleys bordered by high rugged mountains. Disastrous landslides are usually more common during rainy periods, which in the past have caused some of the worst landslides in China. It is estimated that more than 70 landslides have taken place since 1982, causing at least
363 fatalities ( $\mathrm{Li} 2000$ ). Two important examples of these are the Jipazi and Xintan landslides.

The impounding of the Three Gorges reservoir is being carried out in steps: the reservoir level has been raised, at a rate of around $3.3 \mathrm{~m} /$ day, to $135 \mathrm{~m}$ on 11 June 2003 and will be raised to $156 \mathrm{~m}$ in 2007 and then to $175 \mathrm{~m}$, the normal top water level, in 2009. The landslide problem has attracted the attention of the central and local governments and the

Received 2 September 2003. Accepted 15 March 2004. Published on the NRC Research Press Web site at http://cgj.nrc.ca on 18 December 2004.

F.C. Dai, ${ }^{1}$ L.G. Tham, and C.F. Lee. ${ }^{2}$ Department of Civil Engineering, University of Hong Kong, Pokfulam Road, Hong Kong, China.

J.H. Deng. Wuhan Institute of Rock and Soil Mechanics, Chinese Academy of Sciences, Wuhan, China.

K.T. Law. Department of Civil and Environmental Engineering, Carleton University, Ottawa, ON K1S 5B6, Canada.

${ }^{1}$ Present address: Institute of Geology and Geophysics, Chinese Academy of Sciences, Beijing 100029, China.

${ }^{2}$ Corresponding author (e-mail: leecf@hkucc.hku.hk). 
Fig. 1. Location of the landslide.

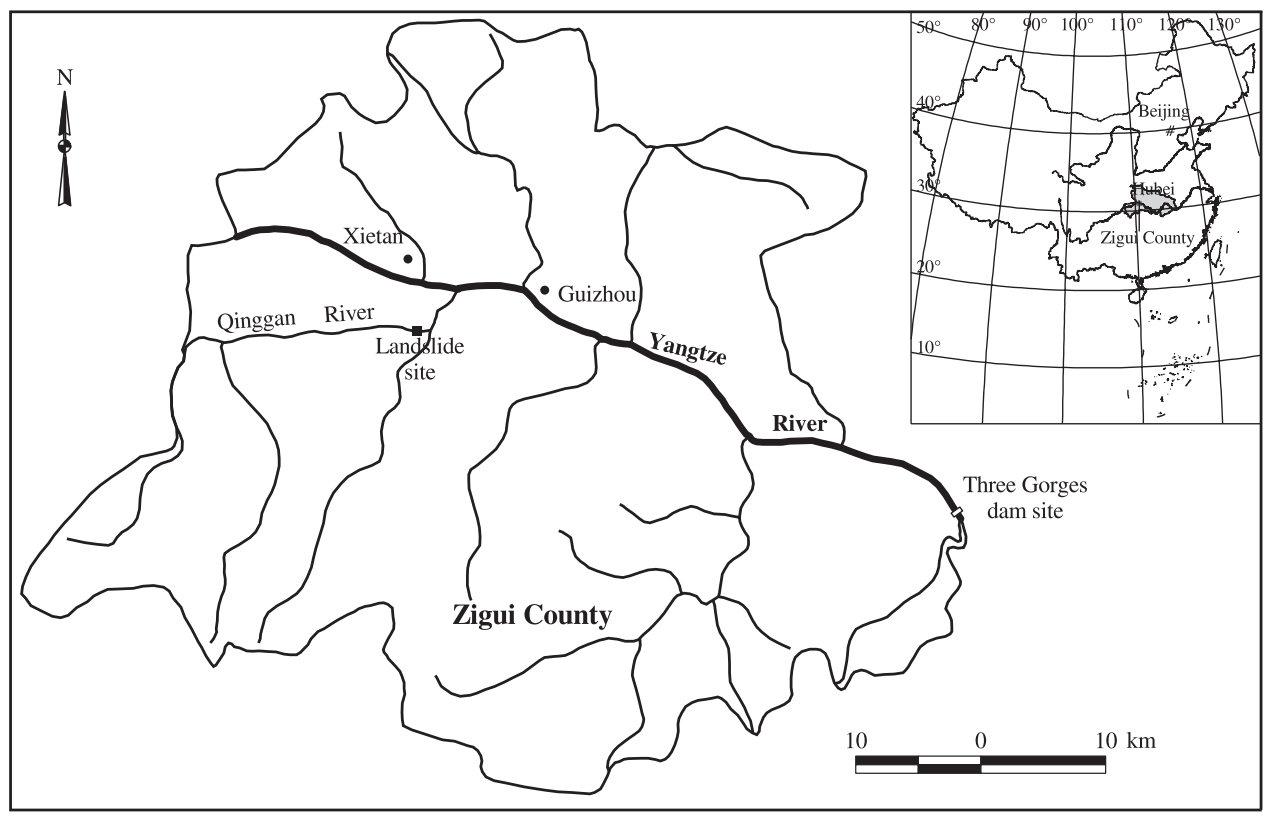

geotechnical community. About 2490 potential landslide sites of a variety of magnitudes were identified along the reservoir slope with a total length of $5300 \mathrm{~km}$ in the Three Gorges area. Landslide hazards associated with reservoir impounding and resettlement were to be mitigated in stages, consistent with the steps of reservoir impounding and resettlement (Ministry of Land and Resources 2001). In the first stage, an investigation and preventive program was planned and had been successfully completed before the first reservoir impounding. In this program, 581 sites associated with the initial reservoir water level of $135 \mathrm{~m}$ were to be mitigated and classified into three types: (i) 198 sites to be remedied; (ii) 232 sites from which existing residents were to be relocated; and (iii) 151 sites to be observed by local residents or monitored with instrumentation, based on the risk estimated using a hazard and risk rating system.

In this note, we describe some of the characteristics and possible causes of the Qianjiangping landslide that occurred in Zigui County on 13 July 2003. This landslide belongs to type iii, i.e., site to be observed by local residents. Indeed, the evacuation was carried out on time.

\section{Site conditions}

Located on the Qinggan River, a tributary of the Yangtze River, the Qianjiangping landslide is about $4 \mathrm{~km}$ upstream from the confluence of the Qinggan River and the main channel of the Yangtze River. It is on the left bank of the Qinggan River in Zigui County, Hubei Province (Fig. 1). The area is characterized by rugged topography, high relief, and deep narrow gorges. The landslide site has a midlatitude continental monsoon climate. Temperature ranges from $-8.9^{\circ}$ to $42{ }^{\circ} \mathrm{C}$, with an annual average of $18{ }^{\circ} \mathrm{C}$. Rainfall is not evenly distributed throughout the year, with large monthly fluctuations. The available rainfall data for 19601985 from the Guizhou Meteorological Station, located approximately $9 \mathrm{~km}$ northeast of the landslide site, indicate that annual rainfall ranges from 733 to $1431 \mathrm{~mm}$, with a mean annual value of $1029 \mathrm{~mm}$. The rainfall from May to September accounts for $66 \%$ of the annual total. November to March is the dry season, and rainfall in this period is about $15 \%$ of the total annual rainfall. From 1: 10000 scale topographic maps with a contour interval of $5 \mathrm{~m}$, the river level of the Qinggan River at the landslide site was estimated to be 85-90 m before the initial impounding of the Three Gorges reservoir.

At the landslide site, a thin mantle of Quaternary deposits overlies the Shazhenxi Formation of Upper Triassic age which comprises weathered sandstone and siltstone interbedded with shale. The Quaternary deposits, derived mainly from in situ weathering, vary from less than $1 \mathrm{~m}$ thick in the upper part of the hillside to $3 \mathrm{~m}$ in the lower part. The hillslope, dipping toward $120-140^{\circ}$, has moderate slope angles ranging from $15^{\circ}$ to $30^{\circ}$, whereas bedding planes dip toward $125^{\circ}$, with an overall dip angle of $23-25^{\circ}$ in the upper part, and may become gentler downslope (Fig. 2). Consequently, bedding planes may daylight at or be shallowly buried in the riverbed of the Qinggan River.

\section{Landslide event}

\section{Landslide process}

At around 0:20 am (Beijing time) on 13 July 2003, a large landslide occurred on the left bank of the Qinggan River (Figs. 2, 3). Witness accounts showed that it took less than 5 min to complete the whole process of landsliding. The landslide has a volume of $20 \times 10^{6} \mathrm{~m}^{3}$, with a maximum width of $800 \mathrm{~m}$ and maximum length of $1100 \mathrm{~m}$. It is estimated that the maximum failure depth is approximately $30 \mathrm{~m}$. The landslide can be classified as a translational rockslide, following Cruden and Varnes (1996). The displaced block of weathered sandstone and shale slipped down along the bedding plane, following the dip direction of the bedding plane, and formed both a main scarp and a surface of rupture. 
Fig. 2. (a) Sketch map showing the extent of the landslide. (b) Cross section at $\mathrm{C}-\mathrm{C}^{\prime}$ in $(a)$.

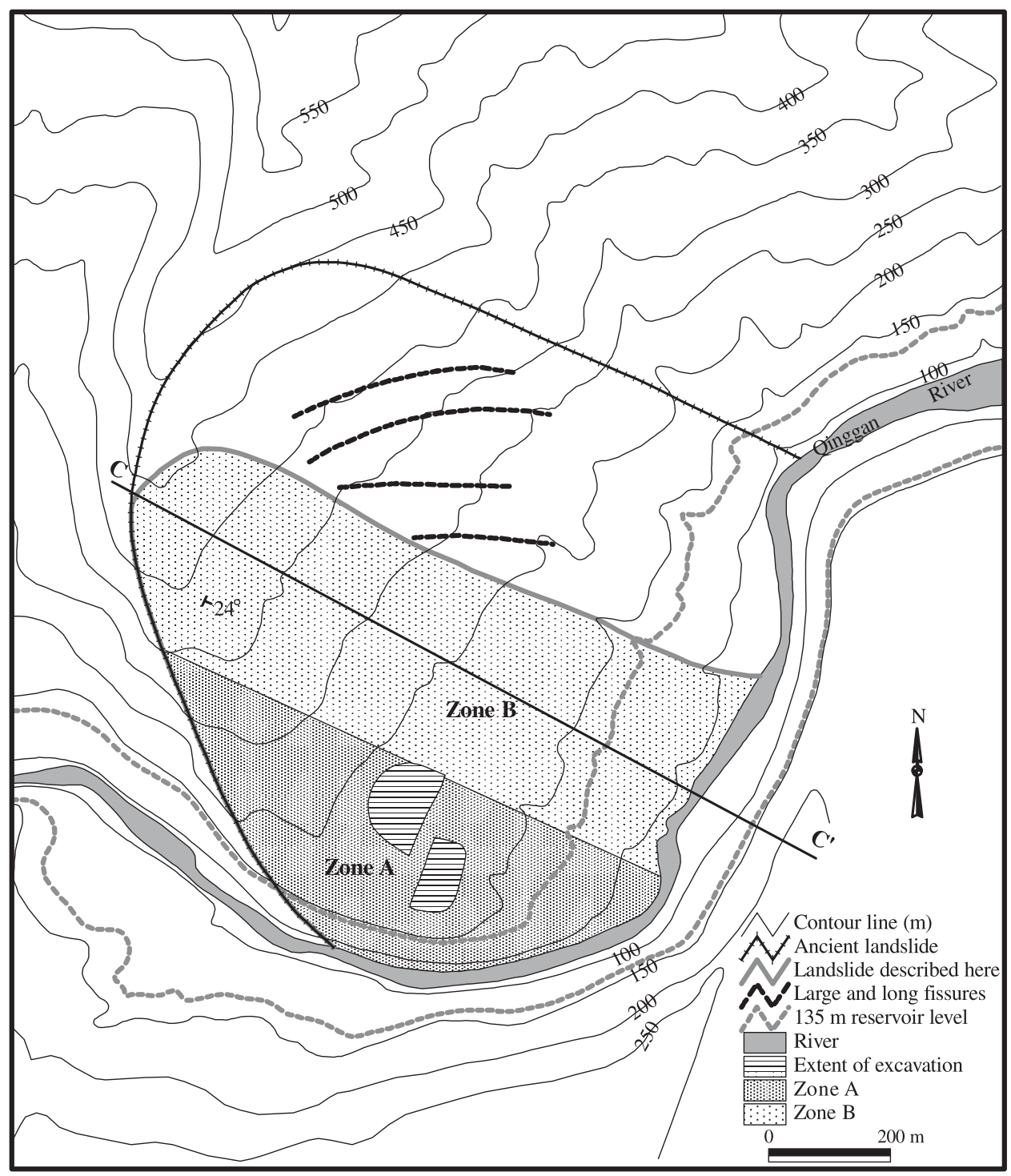

(a)

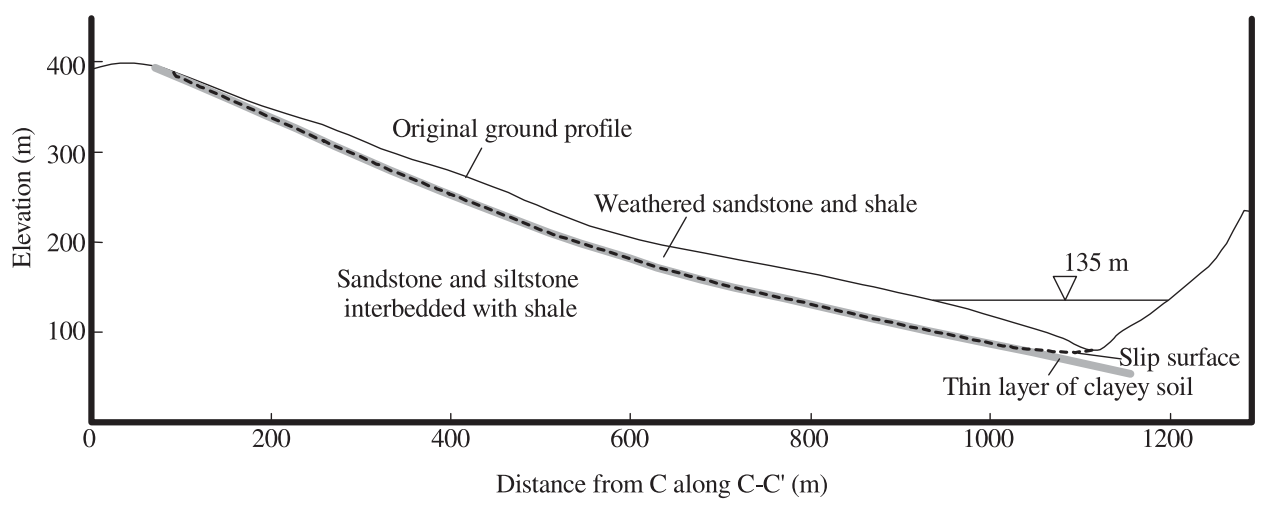

(b)

A post-failure walk-over survey and witness accounts showed that this landslide could be divided into two successive events. This is also evidenced by the fact that there is over $20 \mathrm{~m}$ of differential surface displacement along the common boundary between the right and left portions of the landslide debris. In the first event, the right portion of the 
Fig. 3. An overview of the landslide.

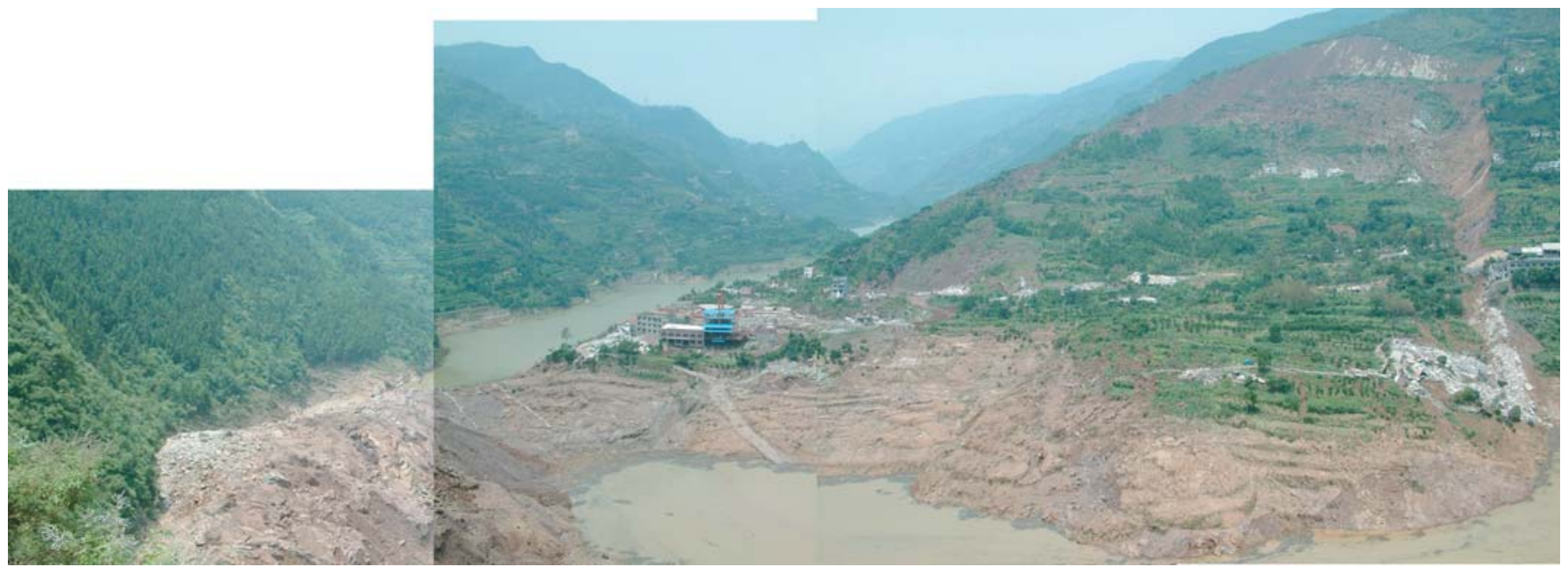

landslide with a volume of about $6 \times 10^{6} \mathrm{~m}^{3}$, as indicated as zone A in Fig. 2, slid down along the bedding plane. It is estimated that for this event the slip plane may daylight at the riverbed, resulting in a high-speed rockslide. The rock mass block travelled a distance of about $240 \mathrm{~m}$. The frontal part of the rock mass ran up the opposite bank of the reservoir, generating a wave. The wave of water was pushed up the opposite steep bank, leaving a trace on the vegetation cover at an elevation of about $150 \mathrm{~m}$ (Fig. $4 a$ ), and then bounced back to the landslide mass and swept away all erodible materials, including a house, grass, and superficial deposits with a maximum elevation of about $165 \mathrm{~m}$ (Fig. 4b). The walk-over survey, however, indicated that vegetation at an elevation of approximately $175 \mathrm{~m}$ fell to the ground due to the wave of water (Fig. 4c). This event blocked the Qinggan River completely and formed an irregular landslide dam (Fig. 3). The landslide debris entering the river was shifted downstream due to obstruction of the steep slope. The landslide dam above the $135 \mathrm{~m}$ water level had maximum and minimum heights of about 178 and $149 \mathrm{~m}$, respectively. In the second event, the left portion of the landslide (zone B in Fig. 2) slid down along the bedding plane with a maximum travel distance of approximately $180 \mathrm{~m}$. Field observations showed that for this slide event, surface features such as houses and highways tilt backward against the landslide scar (Fig. 5). This may indicate that the second slide event was less translational than the first slide event. Other evidence includes extensive fissures in the frontal part of the slide mass, indicating extensive deformation in this area. This block of the landslide mass did not dam the Qinggan River.

The debris deposits consisted mainly of angular coarse clasts surrounded by finer fractions intensely disintegrated from the shale. Though the rock in the debris accumulation is highly fractured, the accumulation retains its bedding plane with an opposite dip compared with that of its original bedding (Fig. 6a). The pebble deposits can be observed on the top of the landslide debris (Fig. 6b). This indicates that the surface of rupture was below the bed of the river and thus the landslide pushed the preslide bed toward the opposite side of the river.

A precursor to this rockslide event started on the morning of 12 July 2003. Witness accounts showed that at around
6:30 am on 12 July, some fine fissures were observed on the concrete floor and walls of a house belonging to a silicon company located in the left and frontal part of the landslide. This phenomenon was reported to the local government immediately. The government officials carried out an immediate site visit to the slope and found that there were some fissures at the toe and upper part at elevations of about $450 \mathrm{~m}$. Simple monitoring of some of the fissures was carried out to understand the temporal change in width of the fissures by attaching a piece of paper across each fissure. At around 9:00 pm, the fissure started to widen and the paper was torn into two pieces (Fig. 7). At around 11:20 pm, the local government decided to evacuate the 1200 people living on the landslide site.

\section{Consequence}

The landslide destroyed the homes of 129 families and four factories, including the silicon company, a brick fabricating factory, a transportation company, and an architectural and construction company. This resulted in about 1200 people being left homeless. In addition, the landslide damaged the electric supply facilities and interrupted the transportation routes. It was estimated that this landslide caused an economic loss of about 80 million renminbi (RMB) (US\$ 10 million).

The wave of water generated by the landslide overturned five boats located upstream and 17 boats downstream, with 10 people missing.

As of 17 July 2003, 14 people were confirmed dead and 10 were still missing. It should be noted that the 14 people killed by the landslide did not believe in the impending danger and were unwilling to leave their homes or insisted on taking their belongings and thus missed the opportunity to leave the site before the landslide.

The landslide dam blocked the Qinggan River completely and formed a lake upstream. The water level of this lake rose gradually in the following days. During the week following the landslide, the water level in the impoundment rose by about $12 \mathrm{~m}$. Following the classification scheme of Costa and Schuster (1988), this blockage is attributable to a type III landslide dam, since the detached mass was in con- 
Fig. 4. (a) A trace left on the vegetation by the wave of water on the opposite bank of the Qinggan River. (b) Erosion caused by the wave of water on the frontal part of the landslide.

(c) Fallen vegetation caused by the wave of water.

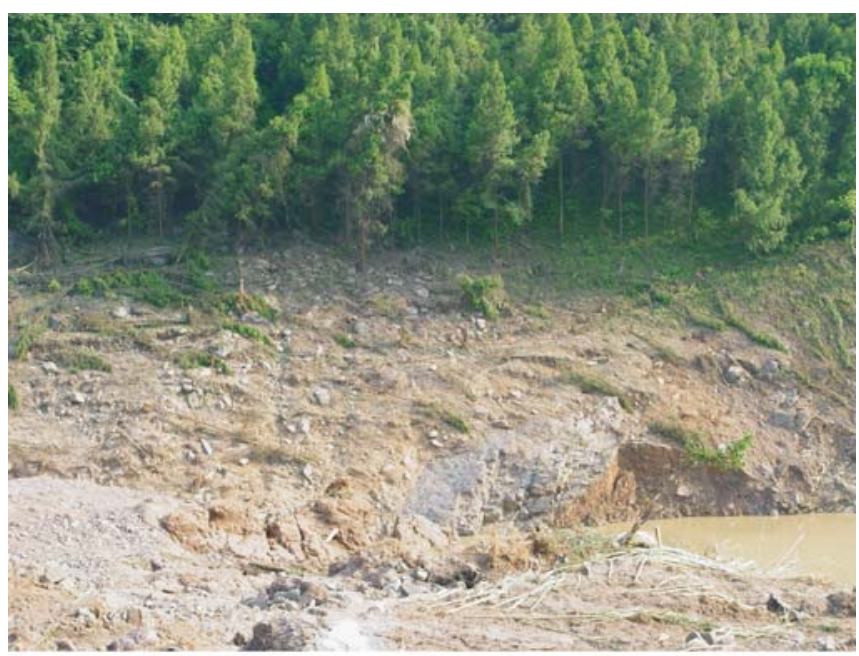

(a)

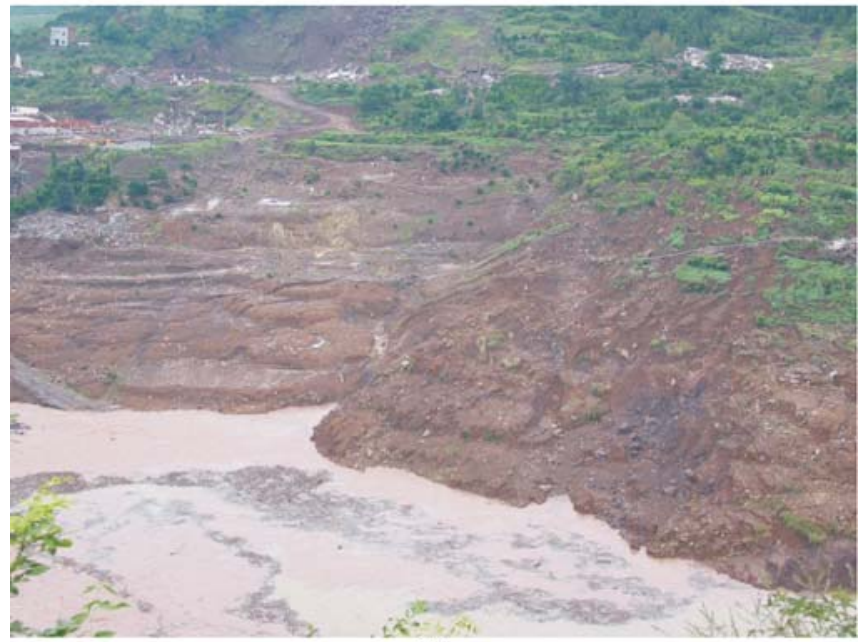

(b)

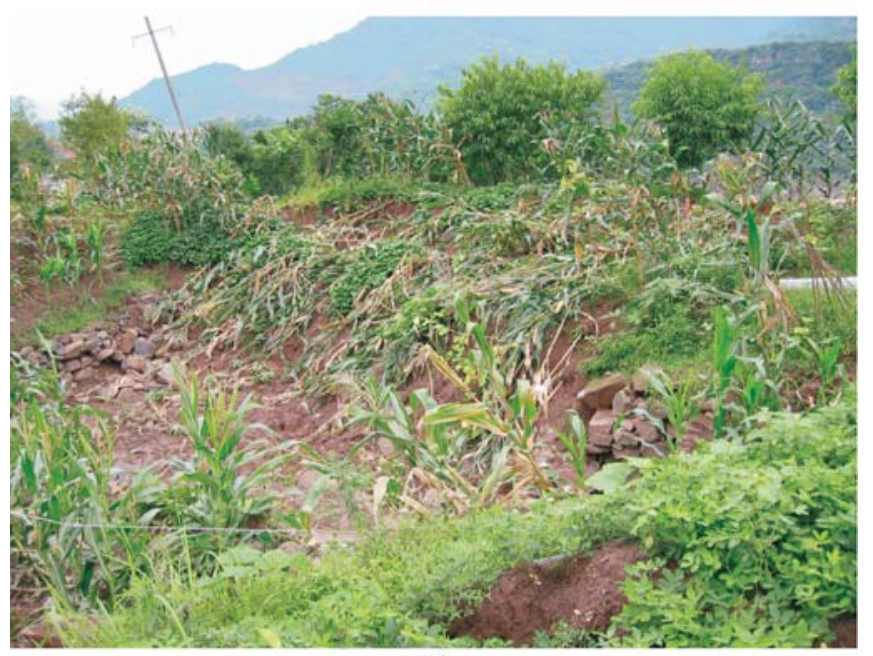

(c)
Fig. 5. Ground cracks and tilting observed on the right portion of the landslide.

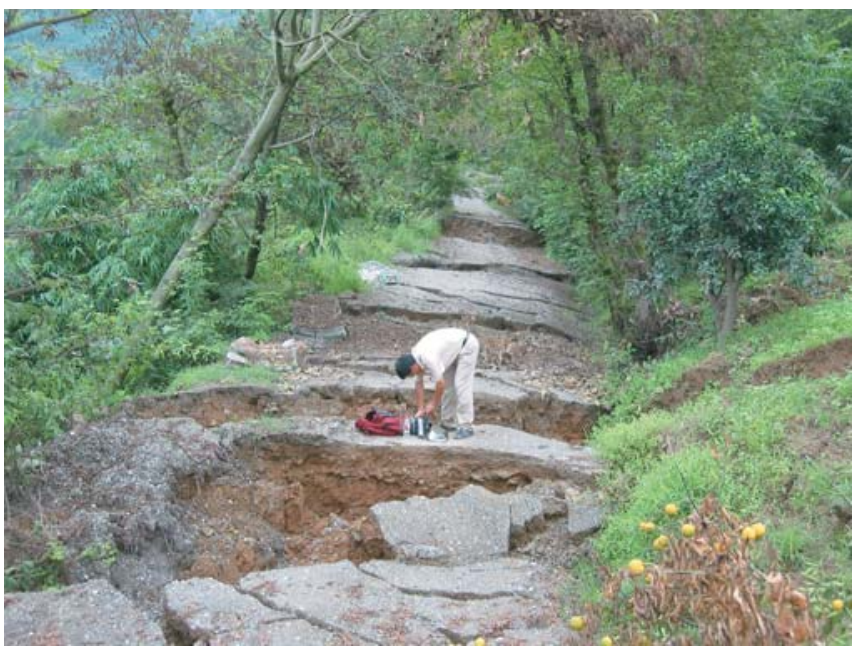

Fig. 6. (a) Landslide debris deposited on the opposite bank of the Qinggan River. The bedding plane can be seen below the landslide debris. (b) Pebble deposits on the top of landslide debris accumulation.

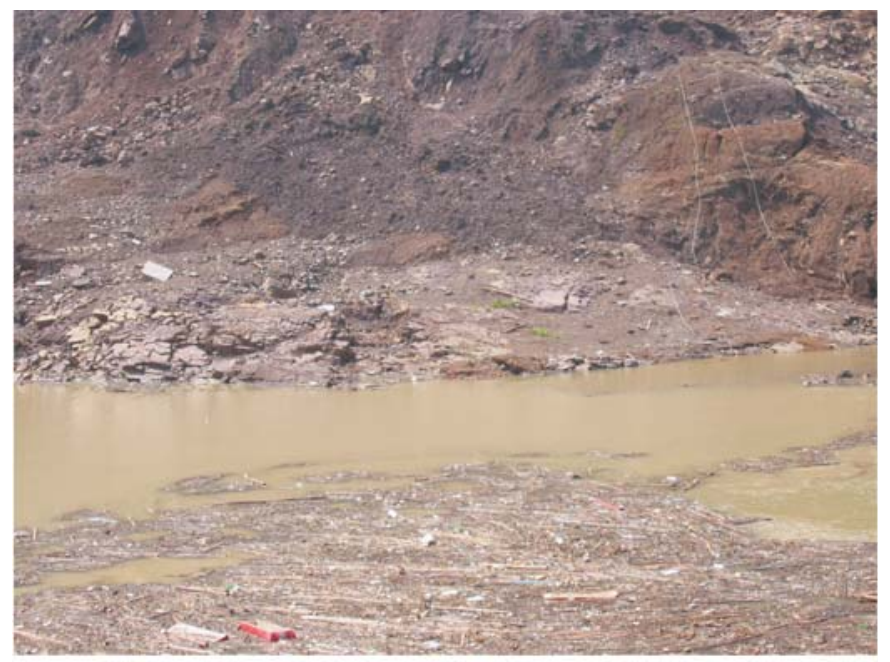

(a)

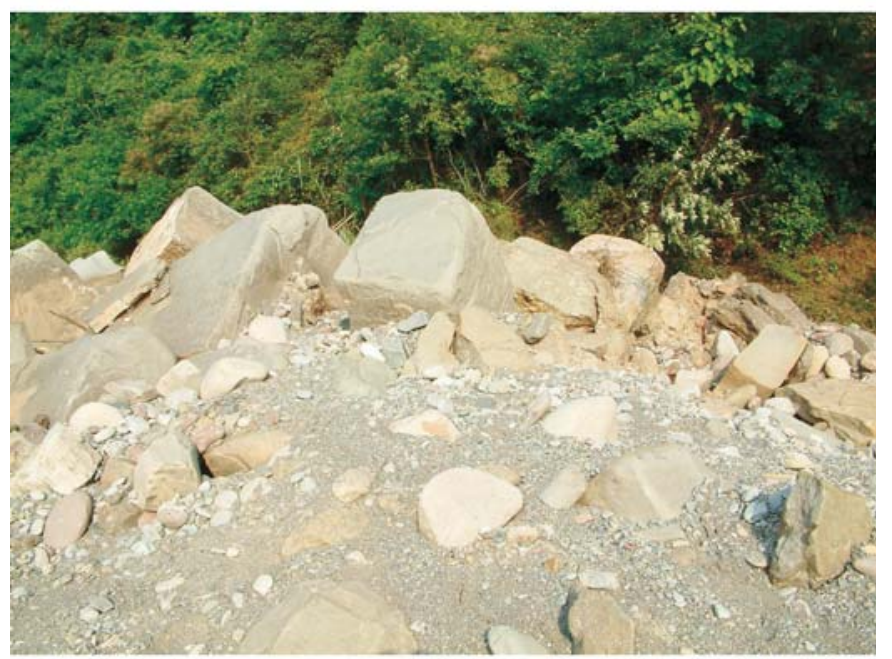

(b) 
Fig. 7. Paper pasted across a fissure. The paper was torn into two pieces when the fissure started to widen.

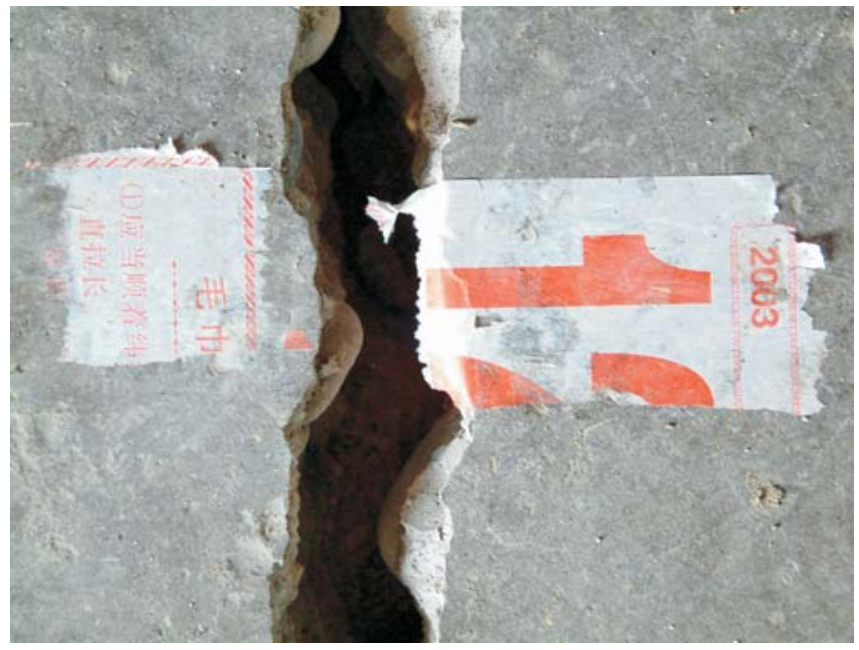

Fig. 8. A channelized diversion excavated for prevention of upstream flooding and possible damage downstream.

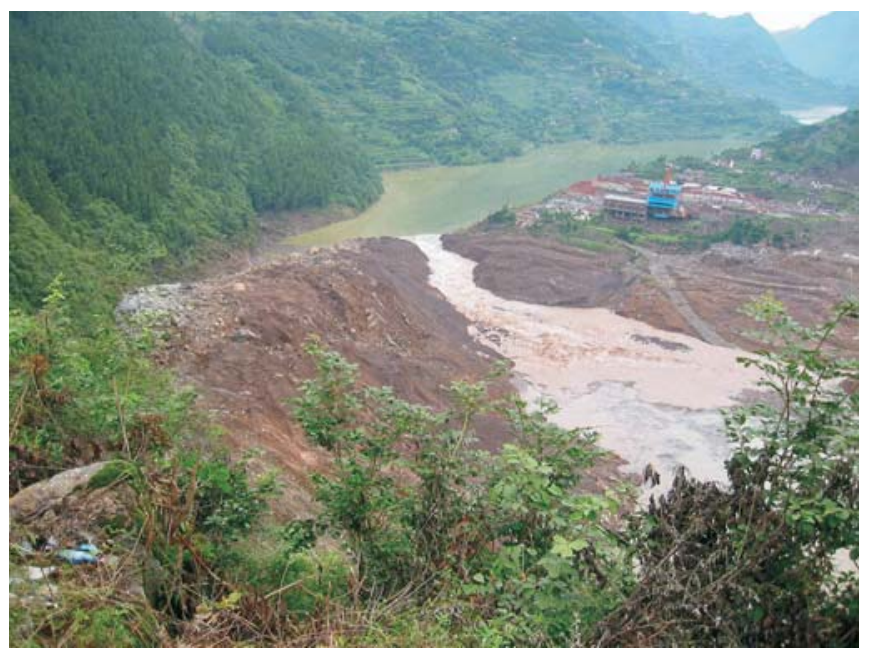

Fig. 9. A long fissure observed on the remaining slope on the left side of the landslide.

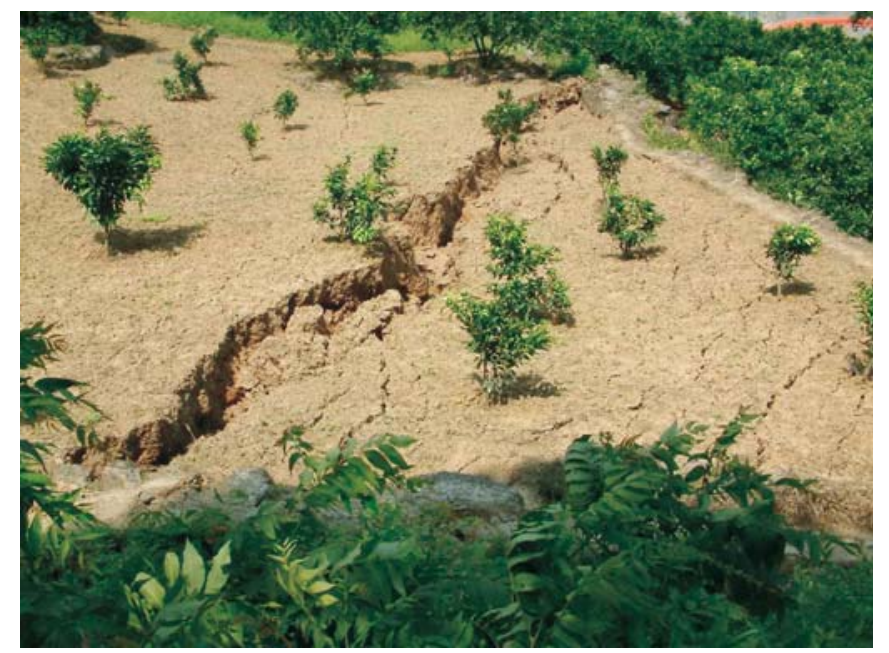

Fig. 10. (a) Slickensided shear surface. (b) Slickensided clayey soil.

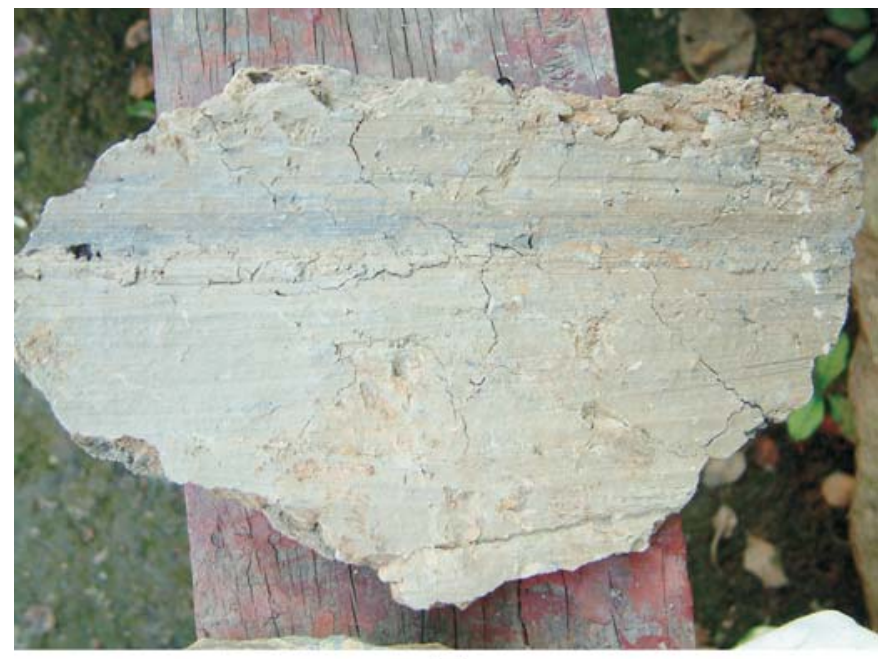

(a)

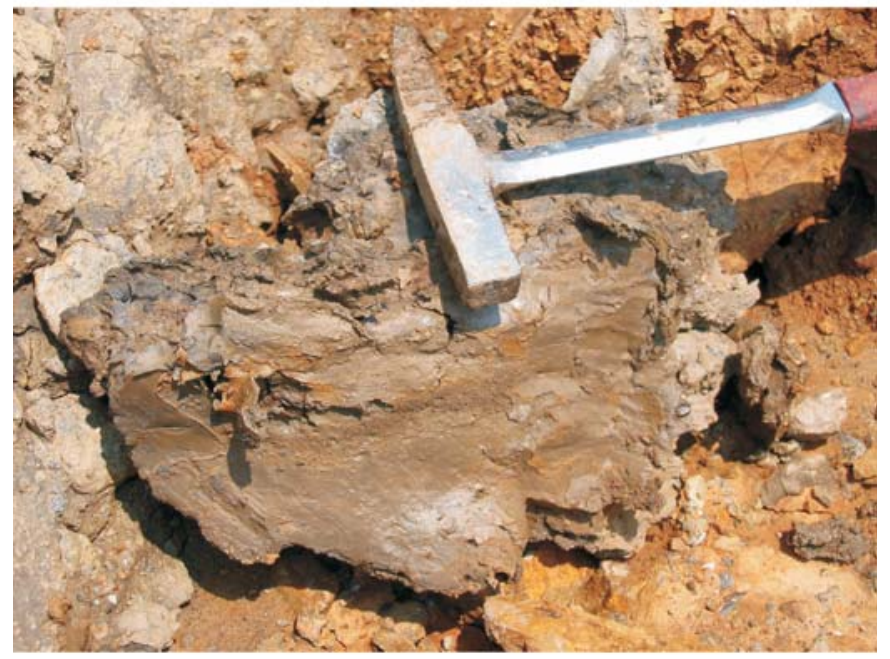

(b)

Fig. 11. Site of the excavation of shale as raw materials for brick fabrication.

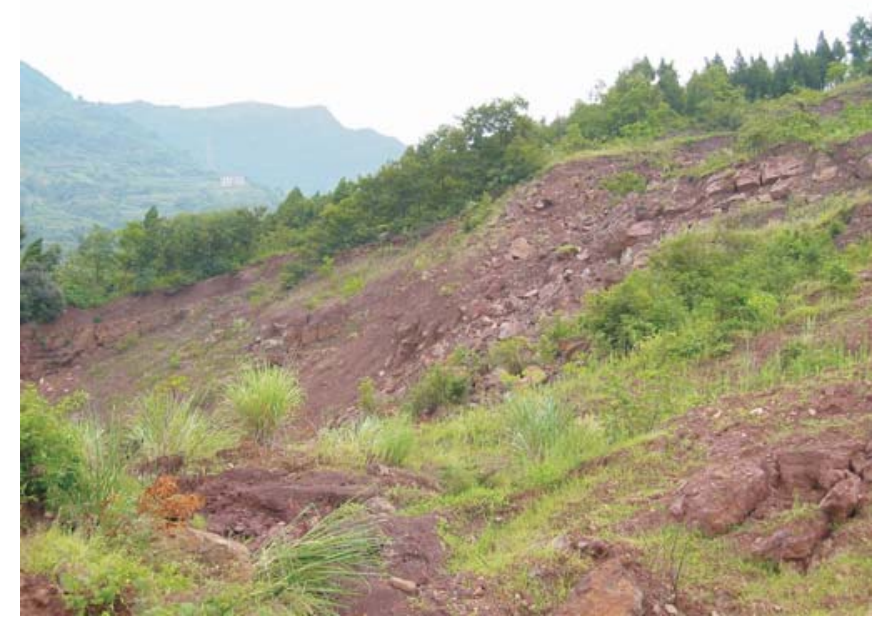


Fig. 12. Daily rainfall and reservoir water level change recorded at Xietan.

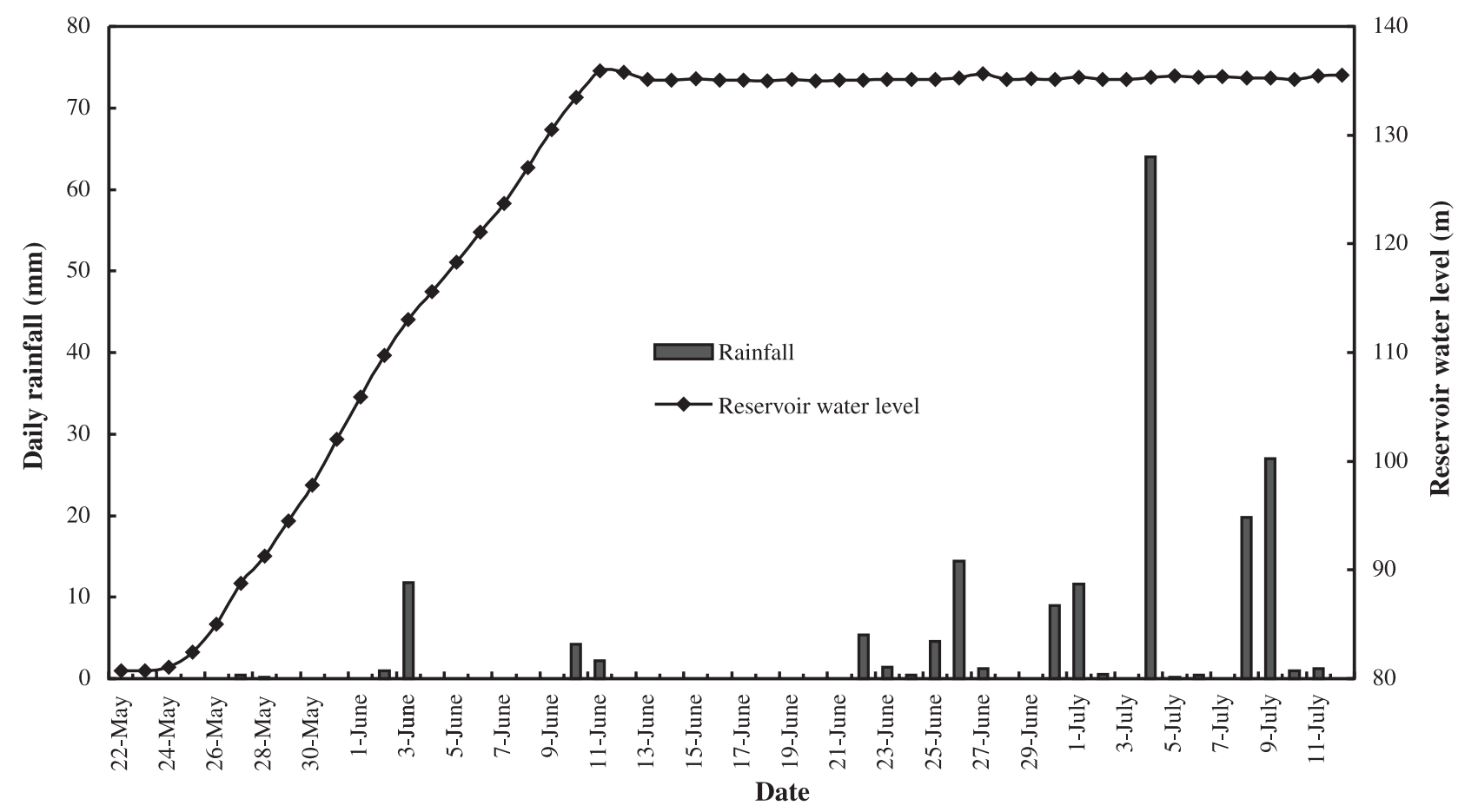

Fig. 13. (a) Groundwater seeping out from the bedrock underlying the slide mass. (b) Small pond of water observed in the landslide debris.

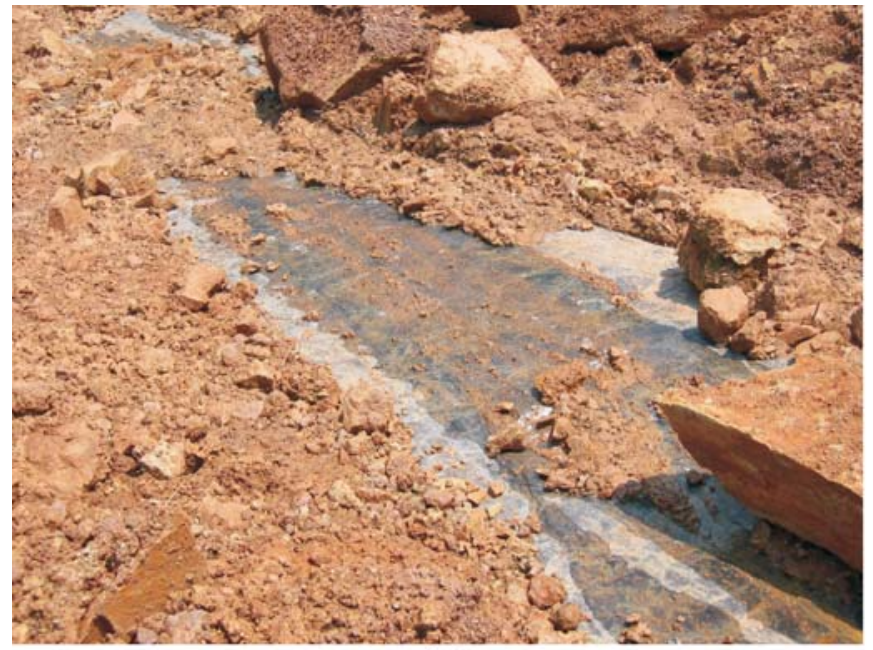

(a)

tact with the opposite slope of the river and the landslide debris was shifted downstream.

At 5:00 pm on 20 July, a channelized diversion with a width of $13 \mathrm{~m}$ was successfully excavated at the saddle of the dam (Fig. 8). The total volume of landslide debris excavated for the diversion was about $3360 \mathrm{~m}^{3}$. This prevented upstream flooding and any possible damage downstream that could be caused by dam breaching.

After the landslide, an extensive distribution of tension cracks was observed within a zone $1200 \mathrm{~m}$ long and $500 \mathrm{~m}$ wide on the remaining slope on the left side of the landslide, as shown in Fig. 2 (see also Fig. 9). Some simple observations on three major cracks were initiated to understand the

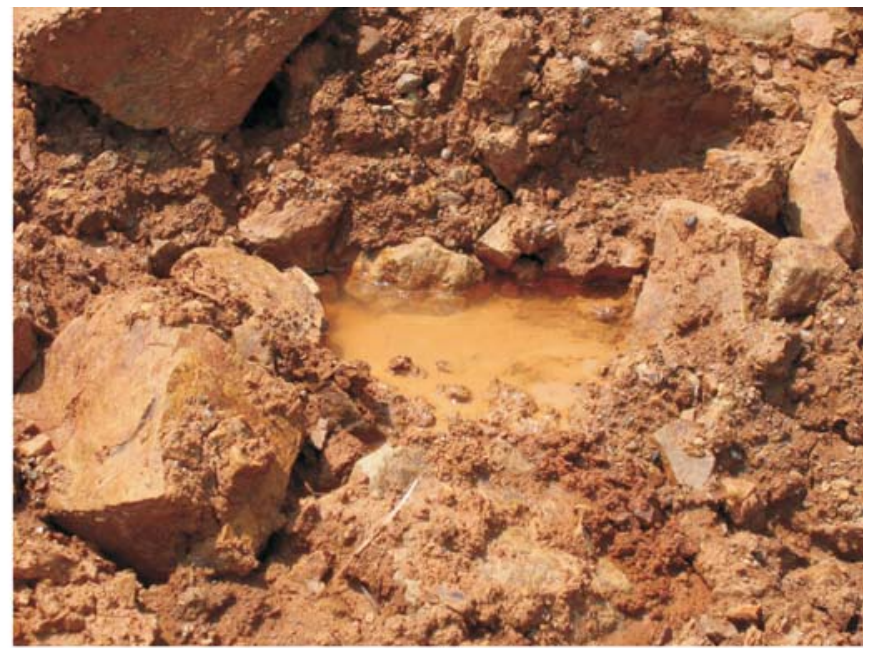

(b)

changes in these cracks. The horizontal widths of these three major fissures increased from $28.5,53$, and $86 \mathrm{~cm}$ at 12:10 pm on 15 July when the observations were initiated to 29 , 54 , and $96 \mathrm{~cm}$, respectively, at 6:40 pm on the same day. Because of concern over the possibility of new landsliding, the local government decided that the 34 people living in this zone should be evacuated.

\section{Possible causes of the landslide}

The geomorphology and lithology of the site are the most important factors contributing to the slope failure. The similarity between the dip of the hillslope and that of bedding 
planes of the lithology and daylighting or shallow burial of the bedding plane in the bed of the Qinggan River render the slope prone to failure. Field observations revealed that the slip plane was along a thin layer of clayey soil with a thickness of several centimetres underlying the weathered sandstone and shale. The bedrock underlying the slip plane is in a relatively intact state compared to the overlying weathered sandstone and shale. It is also important to mention that the present slide is likely a reactivation of an old translational rockslide whose scarp is evidenced by the old scarp shown on the topographic map. The slip zone may have low shear strength as a preexisting shear plane. The weathered sandstone and shale might have acted as highly permeable material that led to the formation of a perched groundwater table in the slip zone above. The slip surface is smooth and slickensided (Fig. 10).

Excavation of the shale as raw material for brick fabrication (Fig. 11) at the middle part of the slope is also a factor contributing to the slope failure. The excavation was carried out in zone A, as shown in Fig. 2, with a depth ranging from 2 to $8 \mathrm{~m}$. The excavation removed the support and created tension cracks on the upper slope. These cracks, wide open joints, and loose overburden on the slope facilitated percolation of water into the slope, thus increasing the pore-water pressure.

Rainfall was a major trigger of this failure. In the period between 22 June and 11 July, the rainfall recorded at Xietan, located $5.5 \mathrm{~km}$ north of the landslide site, was $162.1 \mathrm{~mm}$ (Fig. 12). The prolonged seepage of water through the weathered rock could have increased the pore-water pressure and critically reduced the shear strength of the rock mass along the slip plane. Field observations carried out 1 week after the failure showed that groundwater was seeping out from the bedrock underlying the slide mass (Fig. 13). This could have produced an upward seepage force and high pore-water pressure at the slip plane. The initial impounding of the Three Gorges reservoir raised the water level to $135 \mathrm{~m}$ on 10 June at a rate of approximately $3.3 \mathrm{~m} /$ day (Fig. 12). The rise in reservoir water level drove up pore pressures in the lower part of the shale layers, reducing its strength. It is estimated that a combination of prolonged rainfall and reser- voir impounding are the main causes of the landslide because the rainfall was not heavy compared with previous rainfall events at the landslide site.

\section{Conclusion}

The landslide described in this paper was a typical translational rock failure associated with weathered sandstone, siltstone, and shale. It is estimated that the landslide was caused by the combined effect of the following factors: (i) an exposed bedding interface between the incompetent weathered shale and the competent sandstone that daylights at or is shallowly buried in the bed of the Qinggan River, (ii) the possibility of a preexisting shear plane filled with weak clayey soil facilitating the formation of the slip zone, (iii) excavation of the shale as raw material for brick fabrication on the slope, and (iv) a combination of prolonged rainfall and reservoir impounding.

This landslide occurred at one of the observation sites of the geologic hazard prevention program in the Three Gorges reservoir area. This means that the local residents were required to report any abnormal phenomenon associated with possible failure to the local government. The timely evacuation of the people living at the landslide site demonstrated that this approach is very effective, albeit simple.

\section{References}

Costa, J.E., and Schuster, R.L. 1988. The formation and failure of natural dams. Geological Society of America Bulletin, 100: 1054-1068.

Cruden, D.M., and Varnes, D.J. 1996. Landslide types and processes. In Landslide investigation and mitigation. Edited by A.K. Turner and R.L. Schuster. Transportation Research Board Special Report 247, National Academy of Sciences, Washington, DC. pp. 36-75.

Li, L.R. 2000. Effective prevention of geologic hazards in the Three Gorges reservoir area. Available from www.cigem.gov. $\mathrm{cn} / \mathrm{jcy} / \mathrm{homepage} / \mathrm{html} / \mathrm{zf} / \mathrm{zf} 4 . \mathrm{htm}$.

Ministry of Land and Resources. 2001. A plan of geologic hazard prevention in the Three Gorges reservoir areas. Ministry of Land and Resources, People's Republic of China, Beijing. 